\title{
ERRATA
}

\section{Circular asymmetry of the paleomagnetic directions observed at low latitude volcanic sites}

\author{
Hidefumi Tanaka
}

Earth Planets Space, Vol. 51, No. 12, pp. 1279-1286, 1999

Running head of title page:

“Earth Planets Space, 51, 1279-1286, 2000" should read "Earth Planets Space, 51, 1279-1286, 1999". 